\title{
Classified Advertising and Meetings
}

\section{ANESTHESIA}

$A$ vacancy exists for an anesthelist with FRCPC or eligiblity for same, to join the academic staff of Memorial University of Newfoundland Faculty of Medicine. The successful candidate must be eligible for licensure in Nffd. Clinical responsibilities would be primarily at the General Hospital - Health Sciences Centre, which is the adult tertiary care centre for the province of Newfoundland \& Labrador. The Hospita has a well developed multi-disciplinary Intensive Care Unit and a Pain Clinic in which the Discipline of Anesthesia has a high profile. The Discipline of Anesthesia has a major interest in the University's newly established hyperbaric facility, which consists of a four-chamber diving complex (including a vertical wet chamber) rated at 1,000 feet of seawater depth and capable of mixed gas saturation diving as well as hyperbaric oxygen therapy. An interest in research is essential; a special interest in hyperbaric medicine would be an advantage. In accordance with Canadian Immigration requirements, this advertisement is directed to Canadian Citizens and permanent residents of Canada. Write for further information to: Henry J. Manson, M.B., Ch.B., F.F.A.R.C.S., FRCPC

Professor \& Chairman

Discipline of Anesthesia, Faculty of Medicine Memorial University of Newfoundland St. John's, NF, Canada A IB 3V6

\section{CLASSIFIED ADVERTISING}

As a service to its readers, the Canadian Journal of Anaesthesia is pleased to accept suitable classified advertisements to announce positions available or wanted, meetings, postgraduate courses, or other events or items of interest to subscribers. Rates for classified advertising (for each insertion): $\$ 30$ for first 5 typeset lines, $\$ 5$ per typeset line (or partial line) thereafter. Minimum charge $\$ 30$. Copy mus be received 5 weeks prior to the 1 st of the month of publication. Ad copy, subject to acceptance by the publisher. should be typed double-spaced and mailed or faxed to:

Canadian Journal of Anaesthesia

187 Gerrard Street East

Toronto, Ontario, Canada M5A 2E5

Tel. (416) 923-1449, Fax (416) 944-1228

Specially priced display advertising space

is also available to non-commercial advertisers.

\section{ANAESTHETIST: ONTARIO}

Certified Anaesthetist required to join group currently providing coverage to 360 acute care bed community hospital. Includes active $\mathrm{Ob}$ stetrics, Vascular and Orthopedic surgical programs among others. Currently five certified anaesthetists in on-call group. Reply with curriculum vitae to:

Chief of Anaesthesia

The Brantford General Hospital

200 Terrace Hill Street

Brantford, Ontario N3R IG9

\section{PAIN MANAGEMENT}

Busy pain clinic in downtown Toronto requires physician to work full time or part time. Previous experience helpful but not essential. Remuneration excellent and on "fee for service" basis. For information call or write to:

Director

\section{Pain \& Headache Clinic}

99 Avenue Road, Suite 305

Toronto, Ontario MSR 2G5

Phone: 1-416-924-5146

Fax: $1-416-929-131$

FELLOWSHIP - CARDLAC ANESTHESIA

The Department of Anesthesia, University of Toronto is accepting applications for a 12 month fellowship beginning January 1 , or July 1 , 1991. Experience and training will include all aspects of cardiac anesthesia, ICU and/or clinical research for 2000 open heart patients per year. Candidates must have completed a recognized anesthesia training program and be eligible for academic licensure. Inquiries, $\mathrm{CV}$ and three references should be addressed to:

Sallie J. Teasdale, M.D

Director of Candiac Anesthesia

The Toronto Hospital

200 Elizabeth Street

Toronto, Ontario, Canada M5G 2C4

\section{Meetings - Canada}

British Columbia Anaesthetists' Society/ Washington State Society of Anaesthetists December 7-9, 1990

Vancouver, British Columbia

For Information:

Ms. Ellen MacNeill

c/o BCMA

B.C. Anaesthetists' Society

II5-1665 West Broadway

Vancouver, B.C.

V6J 5A4

Telephone: (604) 736-5551 (ext. 234)

Fax: (604) 736-4566

Second International Symposium on

Paediatric Pain

April 23-27, 1991

Montreal, PQ

For Information:

Pain Secretariat

3450 University Street

Montreal, PQ H3A 2A7

Telephone: (514) 398-3770

Fax: (514) 398-4854

Second International Symposium on Pain

May 1-4, 199!

Montreal, Quebec

For Information:

Pain Secretariat

3450 University Street

Montreal, Quebec

H3A 2A7

Telephone: (514) 398-3770

Fax: (514) 398-4854

Canadian Anaesthetists' Society

48th Annual Meeting

June 21-25, 1991

Quebec City, Quebec

For Information:

Ms. Ann Andrews

Canadian Anaesthetists' Society

187 Gerrard Street East

Toronto, Ontario

M5A 2E5

Telephone: (416) 923-1449

Fax: (416) 944-1228 
The Pharmacology of Thermoregulation 8th International Symposium

August 26-30, 1991

Kananaskis Village, Alberta

For Information:

Mrs. Grace Olmstead

Department of Medical Physiology

Faculty of Medicine, The University of Calgary

3330 Hospital Drive N.W.

Calgary, Alberta T2N 4N1

Telephone: (403) 220-4473

\section{Divisional Meetings - Canada}

\section{Atlantic Regional Meeting}

November 22-25, 1990

Halifax, Nova Scotia

For Information:

Dr. A.J.M. Clark

Department of Anaesthesia

Victoria General Hospital

Hadifax, Nova Scotia

B3H 2 Y9

\section{Other Meetings}

44th Postgraduate Assembly in

Anesthesiology

December 8-12, 1990

New York, New York

For Information:

Mr. Kurt G. Becker

New York State Society of Anesthesiologists

41 East 42nd Street, Suite 1605

New York, New York

10017

Telephone: (212) 867-7140

Fax: (212) 867-7153

Ninth Annual Symposium

Clinical Update in Anesthesiology

January 12-19, 1991

Hilton International, Barbados

For Information:

G. Silvay, M.D., Ph.D

Mount Sinai Medical Center

1 Gustave L. Levy Place, Box 1010

New York, NY 10029-6574

American Academy of Pain Medicine

Annual Meeting

January 18-19, 1991

Miami Beach, Florida

For Information:

Ms. Carol Endicott

American Academy of Pain Medicine

5700 Old Orchard Road, Ist Floor

Skokie, IL, 60077-1024

Telephone: (708) 966-5595
Biennial Western Conference on

Anesthesiology

Clinical Update in Anesthesiology

February 3-8, 1991

Maui, Hawaii

For Information:

Murray G. Atnikov, MD

c/o P.O. Box FI10-63

Blaine, WA 98230

Telephone: (604) 874-5291

New Zealand Society of Anaesthetists

"Recovery from Anaesthesia"

February 23-24, 1991

Christchurch, New Zealand

For Information

Dr. Cam Oldin

Department of Anaesthesia

Christchurch Hospital

Private Bag, Christchurch

New Zealand

Riviera Medicine, Pain and Spine

March 6-9, 1991

Menton, France

For Information:

Dr. J.P. Lauren

Clinique de l'Hermitage

18 rue Paul Morillo

06500 Menton

France

Fax: (33) 93-57-04-04

International Anesthesia Research Society

65th Congress

March 8-12,1991

San Antonio, Texas

For Information:

International Anesthesia Research Society

2 Summit Park Drive

Suite 140

Cleveland, Ohio

44131-2553

Telephone: (216) 642-1124

6ème Journées de la SFUM

4èmes Journées d'Enseignement des

Infirmiers et des Infirmières de l'Urgence

les II-13 avril 199!

Genève, Suisse

Renseignements:

Secrétariat

Symprog SA (agence pour l'organisation de Congrès)

108 re de Frontenex

1208 Geneve

Suisee

Téléphone: $(+4122) 7863744$

Fax: $(+4122) 7864080$ 6th International Symposium on Computing in Anaesthesia and Intensive Care

April 15-18, 1991

Hamamatsu, Japan

For Information:

Kazuyuki Lkeda

Chairman, Organizing Committee

c/o Department of Anesthesiology

Hamamatsu University School of Medicine

3600 Handa-cho, Hamamatsu, Shizoka

431-31, Japan

Ist Asian-Oceanic Symposium on

Regional Anesthesig

May 18-19, 199.

Taipei, Taiwan

For Information:

Prof. J.H. Lee

P.O. Box 26-473

Taipei, Taiwan 10713

5th Annual Paris in the Spring

Meeting for Cardio-Thoracic and Vascular

Anesthesiologists

May 26-June 2, 1991

Paris, France

For Information

G. Silvay, M.D., Ph.D.

Mt. Sinai Medical Center

1 Gustave L. Levy Place, Box 1010

New York, NY 10029-6574

Joint Meeting of the Australian Society of Anaesthesists and the Canadian

Anaesthetists' Society

October 12-16, 1991

Brisbane, Australia

For Information:

Dr. J.P. Bradley

Conference Chairman

P.O. Box 1280

Milton, Queensland

Australia 4064

Telephone: (617) 369-0477

Fax: (617) 369-1512

7th Asean Congress of Anaesthesiologists

November 6-9. 1991

Kuala Lumpur, Malaysia

For Information:

Dr. S.W. Lim

Pantai Medical Centre

59100 Kuala Lumpur

Malaysia 